\title{
Circumstances excluding criminal liability under the criminal law of the Muslim countries
}

\author{
Dana Rizayeva ${ }^{1^{*}}$, and Ammar Manna ${ }^{1}$ \\ ${ }^{1}$ Peoples' Friendship University of Russia, 117198, 6 Miklouho-Maclay str., Moscow, Russia
}

\begin{abstract}
In Islamic criminal law there are no institutions the general part, in that connection, it shared the list of circumstances that exclude the criminality of an Act, not developed. In Islamic criminal law, such circumstances, according to the analysis of some of his sources are not reaching the age of responsibility, a State of insanity, mislead, commit a crime under duress, self-defense, urgency, as well as remorse. The article is devoted to the characterization of the circumstances excluding criminal liability under the criminal law of the Muslim countries professing the Anglo-Saxon system of law. Main purpose is to form an idea of the role the circumstances excluding criminal liability under the criminal law of the Muslim countries professing the Anglo-Saxon legal system in modern conditions based on foreign legal literature, and an analysis of the criminal law. The hallmark of Muslim law is a priority of the religious laws of Islam, which govern all aspects of the life of Muslims. The question of the role of the circumstances excluding criminal liability under the criminal law of the Muslim countries professing the Anglo-Saxon legal system in modern conditions is covered in Islamic law with the aim of precise qualification of perfect a criminal offence, with a view to establishing the legality of the Act.
\end{abstract}

\section{Introduction}

At present, in spite of onward social development in various areas of life activity, religion has not lost its regulatory role. The religious norms, to certain extent, have influence on public relations in various states of the modern world. The world religions thus take a special place in the modern world including Islam, which formed a large religious legal system operating in many countries.

The criminal law of the Islamic countries operates as an integral part of the Muslim religion appeared in VII century and extended to the Near-Eastern region, Middle East region, the North Africa and particular states of South-East Asia. The criminal law of these states is virtually considered to be an integral element of Islam and directed at protection of its main values [1].

In the Islamic criminal law there are no institutes of the General part, in this connection, the general list of circumstances, which exclude a criminality action, is not developed in it. In the Islamic criminal law, according to the analysis its some sources conducted non-

*Corresponding author: dana.rizaeva@mail.ru 
reaching of the age of liability, a state of mental incompetence, wrong belief, commitment of a crime under force, necessary defense, state of extreme emergency as well as repentance are referred to such circumstances.

\section{Methods:}

Methodological basis of scientific articles constitute a set of methods and techniques of scientific knowledge, inherent science of jurisprudence. In particular, the study used comparative-legal, dialectic, structural-functional, formal-logical methods.

\section{Results}

The hallmark of Muslim law is a priority of the religious laws of Islam, which govern all aspects of the life of Muslims. The question of the role of the circumstances excluding criminal liability under the criminal law of the Muslim countries professing the AngloSaxon legal system in modern conditions is covered in Islamic law with the aim of precise qualification of perfect a criminal offence, with a view to establishing the legality of the Act.

The determination of circumstances, which exclude criminality and punishability of a criminal action, is directly connected with determination of a crime and, in this connection, excluding occurrence of criminal liability. It should be noted that such circumstances would highlight a meaning of signs of a crime committed. In this connection, it may be noted that circumstances, which exclude criminal liability, indicate absence in the person's actions of any objective and subjective grounds for making him answerable for criminal liability.

So, in Sheriat and Jordan criminal legislation, which may be referred to the countries professing the Anglo-Saxon system of the law, the following kinds of circumstances are provided, which exclude criminal liability: restraint of a person to commitment of a crime, necessity of commitment of a criminal action, mental incompetence of a criminal, his alcoholic and narcotic intoxication, non-achieving by a criminal of criminal liability age, commitment of actions included in legal limits of exercising of his right, performance of an order, use of corporal punishments by parents to own children, carrying out of professional functions. The same circumstances of release from criminal liability, except the two latter are provided by Palestine CC. [2]

The criminal liability age occurrence is considered the age of the person's puberty, reaching by such person of a full age. In Saadi Shirazi's opinion, it is stated in the books that a full age is established in presence of the following signs: upon reaching of fifteen years old, occurrence of pollution or menstruation and appearance of hair in front. As the poet states further, actually a full age has only one sign expressed in a fact that you have taken care of service to the God more than of pleasure of your flesh and who has no such property may not be considered as a full age. [3]

In respect of a full age at Islamic legal schools there is no common opinion. So, in accordance with some sources [4], the person may not made answerable in general until 9 12 years old and upon reaching of the age from 9-12 to 15-18 years old making answerable for criminal liability assumes determination by a judicial body of the fact of a full age of the accused.

The mental incompetence in the Islamic criminal law is considered within the frameworks of a moral element of the criminal action.

Article 14 of Palestine CC provides possibility for release from criminal punishment of those, who has fainted or lost the tight to choice upon commitment of a crime owing to excessive intoxication or as a result of taking a large dose of narcotics not depending of 
their kind and quality, if the person has been forced to take them not of his will and desire. [5]

In this connection, not any alcoholic or narcotic intoxication excludes occurrence of criminal liability but only such, upon which the person has been forced to take them not of his will and desire.

The classical science of the Islamic criminal law specifies that ignorance of the criminal of illegality of the action made by him that is confirmed by swear or oath shall be considered as a circumstance, which excludes criminal liability. In the criminal-legal doctrine of the Muslim states of a modern period the said wrong belief has not remained in a pure state. [6]

However, as the British researchers of the modern Islamic law consider [7], an actual mistake or wrong belief is the ground, which excludes criminal liability in the following cases:

1) wrong beliefs for the cause of facts and 2) wrong beliefs for the cause of the law.

The wrong belief for the cause of facts is recognized, when the criminal considers that his behaviour is legal since legal mistakes are supposed him in respect of a person or objects.

The moment in respect of wrong belief for the cause of the law is of interest, which may be a result of his ignorance of the law or ignorance of its particular details. [8]

The Islamic criminal law directly specifies that a reasonable person should know basis of the law and main prohibitions in respect of larceny, wine use, for the cause of attitude to a life, other persons, in respect of adultery, etc. The criminal law supposes ignorance of main prohibitions of neophyte in Islam as well as the persons who have arrived in the territory of Moslems from other states. [9]

The restraint also refers to the circumstances, which exclude criminal liability in the Muslim countries.

In accordance with Sheriat norms the person may not be involved in criminal liability, which put in such position when he is forced to commit a crime under a threat of death or causing to him of a serious physical injury if it refuses of commitment a crime. However, such provision is not extended to commitment of killing. It is thought that at the heart of such norm there is a rule in accordance with which it is impossible to rescue own life at the cost of a life of the other person. [10]

The restraint is connected with a criminal action characteristic as a conscious strongwilled act. The Islamic criminal law considers in detail the restraint as a circumstance excluding criminal liability. For example, jurist Abdel Kader Ode determines the following obligatory conditions for excluding of liability upon application to the person of a physical violence:

- a crime is committed for rescue of oneself and his relatives from a death or permanent injury;

- a person could not avoid realization of threat in his address otherwise;

- a person threatening realization of threats was nearby and had a real possibility of its realization immediately. [11]

\section{Discussion}

The serious attention in the Islamic criminal law is given to cases of restrict of persons not reached a full age, which owing to the age peculiarities, their ability to evaluate events may appear to be less endurable than adults. [12]

The Islamic legal school provides that the person committed a crime may not be involved in liability, if it is caused by a task to protect himself or own property or to protect other persons and their property from a danger, which is not caused deliberately by him. 
The necessity is not extended to those persons who should in accordance with the legislation to expose his life and health to a danger.

The person is released from criminal liability, who commits an action qualified as a crime if he presents a proof that he has committed such action for prevention of the result entailed a harm caused or heavier harm for it, his honour or property, or for other persons, their honour and property, which are under his control or under his direct jurisdiction. The condition of release is a fact that the person has committed such crime within a necessary and reasonable scope for the purpose of achievement of the aim on ratability of a harm caused to a harm prevented. [13]

The said determination of necessity should be considered as an extreme necessity.

So, in accordance with Art. 341 of Jordan CC the following actions are considered as necessary defense only:

1. Killing of the other person or inflicting wounds and striking blows in the course of protection of oneself or the other person provided that an attack and protection committed are executed simultaneously; an illegal attack is illegal; the protected person do not have any other way to avoid such attack, except killing or inflicting wounds and striking blows;

2. Killing of the other person or inflicting wounds and striking blows upon realization of protection of own property or property of the other person which is under his jurisdiction in that case that protection is executed upon stealing or theft, which is accompanied by violence. [14]

The second condition of legitimacy of a necessary defense, which is referred to an encroachment, is considered to be its availability. The harm caused, when an attack has not been begun yet or when an attack has already ended, may not be a necessary defense.

The third condition of legitimacy of a necessary defense, which is referred to an encroachment, is reality of an encroachment committed really and not just in imagination of "being protected".

The fourth condition of the phenomenon under study is considered performance of the criminal legislation requirement that upon realization of protection in excess of its limits is not supposed i.e. protection should be committed within boundaries of necessity of commitment of actions on repulse of an attack and not pursue intention to cause an excessive harm to the person, who has committed an illegal attack.

It is seemed that such decision is quite justified. The indication in determination itself of a necessary defense on conditions of its recognition as legal (observance of a rule on nonexcess of its limits) will orientate the attention of law enforcement bodies on determination of compliance of an attack and protection that leads to mistakes in use of the institute of a necessary defense, when the actions undertaken for repulse of an attack are regarded as excess of limits of a necessary defense. [15]

Though the Islamic criminal law does not specify directly an extreme necessity (Art. 18 of Palestine CC and Art. 89 of Jordan CC) as the grounds for release from criminal liability but upon consideration of the criminal law norms of particular states it follows that such norms may be applied upon solving of issues, which are connected with an extreme necessity as well. It is noted that the person may not refer to realization of actions in an extreme necessity, if according to the law it should prevent an imminent danger. [16]

In majority of Criminal Codes of the Arabian states following the French criminal legislation, the special norms on an extreme necessity are not provided. Undoubtedly, absence of such standard provisions in the criminal legislation does not mean once again that the law enforcement persons, which are guided by the doctrine, do not use such institute of the criminal law. At the same time, the expediency of entering of the said norms in the criminal code does not raise any doubts. [17]

A special kind of release from criminal liability, which is possible only upon commitment of certain crimes supposing repentance by the Article 14 of Palestine CC 
provides possibility for release from criminal punishment of those, who has fainted or lost the tight to choice upon commitment of a crime owing to excessive intoxication or as a result of taking a large dose of narcotics not depending of their kind and quality, if the person has been forced to take them not of his will and desire criminal doctrine, is repentance. Showing own repentance, the criminal confirms that he has already changed and it is not necessary to expose him to punishment.

All Sunni legal schools suppose a repentance as a circumstance excluding liability for ridda (except an insult of Prophet Mohammed) and for revolt. [18]

For ridda a term is given to the criminal, within which he may repent and return to Islam and thus receive release from criminal liability. The rebel's repentance is recognized only in the event that the rebel has surrendered to a legitimate authority independently. Some schools establish a certain term within which the criminal should prove a gravity of his intentions. [19]

In Shiites' opinion, some Shafiites' and Hanbalits' opinion, the criminal's repentance should be proved by a court and a fact of prevention from expected intentions to commit a criminal action should be established. In the said cases, criminal liability remains and the person is released from punishment only. [20].

\section{Conclusion}

In conclusion of the study carried out it should be noted that in the Islamic criminal law such circumstances, according to the analysis of some of its sources conducted, include: non-reaching of the age of liability, a state of mental incompetence, ignorance, commitment of a crime under restraint, necessary defense, extreme emergency as well as repentance. In respect of a full age there is no single opinion at Islamic legal schools. So, in accordance with some sources, a person may not be made answerable in general until 912 years old and upon reaching of the age from 9-12 to 15-18 years old involvement in criminal liability supposes determination by a judicial body of the fact of a full age of the accused. The mental incompetence in the Islamic criminal law is considered within the frameworks of a moral element of the criminal action. Not any alcoholic or narcotic intoxication excludes occurrence of criminal liability but only such upon which the person has been forced to take them not of his own will and desire. The classical science of the Islamic criminal law specifies that ignorance of the criminal of illegality of the action committed by him that is confirmed by swear or oath is considered to be a circumstance, which excludes criminal liability. The ignorance for the cause of the facts is recognized, when the criminal considers that his behaviour is legal since legal mistakes are supposed by him in respect of a person or objects. In accordance with Sheriat norms the person may not be involved in criminal liability, which is put in such position, when he is forced to commit a crime under a threat of death or causing to him of a serious physical injury if it refuses commitment of a crime. However, this provision is not extended to commitment of killing. The Islamic legal school provides that the person committed a crime may not be made answerable, if it is caused by a task to protect himself or own property or to protect other persons and their property from danger, which is not caused deliberately by him. The necessity is not extended to those persons, who should in accordance with the legislation to expose a life and health to a danger. Though the Islamic criminal law does not specify directly an extreme emergency as the grounds for release from criminal liability but upon consideration of criminal law norms of particular states follows that such norms may be applied upon solving of issues, which are connected with an extreme emergency. The repentance is a special kind of release from criminal liability, which is possible only upon commitment of certain crimes supposing repentance by the Islamic criminal doctrine. 
Showing own repentance, the criminal confirms that it has already changed and it is not necessary to expose him to punishment.

\section{References}

1. Yu.A. Ivanov, Judicial Power and Criminal Trial 4, 297 (2015).

2. L.P. Rasskazov, M.R. Kangezov, Society and Law 1, 24 (2010).

3. G.M. Kerimov, Shariat: Law of Life of Moslems. Sheriyat's Responses to Problems of Modern Time (SPb, 2012).

4. A.V. Petrovsky, Muslim Criminal Law and Peculiarities of Criminal Legislation of Muslim States: Monogtaphy (Krasnodar, Kuban State University, 2013).

5. I.Yu. Kozlikhin, Science of Law 3(296) (2011).

6. S. A. Chunikhin, E. A. Kuzmin, L. V. Pushkareva, Entrepreneurship and Sustainability Issues 6(4), 1663-1679 (2019). DOI:10.9770/jesi.2019.6.4(8)

7. M. Al Awabdeh, History and Prospect of Islamic Criminal Law with respect to the Human Rights. Dissertation zur Erlangung des akademischen Grades Dr. jur. (Berlin 2005).

8. A.T. Nail, Sources of Criminal Law Existing in Palestine: Dis. ... Cand of Jurisprudence (Moscow 1994).

9. Zh.D. Akhkumbekova, On some general issues of relation of religion norms and law in Muslim legal system // Black Holes in the Russian Legislation. 2012. No 5.

10. G.F. Yelayan, Basis of Muslim Criminal Law (Makhachkala, 2002).

11. V. Alpatov, IOP Conference Series: Materials Science and Engineering 463(3), 032102 (2018). DOI: 10.1088/1757-899X/463/3/032102

12. R. Repp, 'Qanun and Shari' $a$ in the Ottoman context, in Islamic law: social and historical context (London, 1988).

13. G.F. Yelayan, Liability for Encroachment on Property under Muslim Criminal Law: Dis. ... Cand of Jurisprudence. M., 2000.

14. M. S. Najm. Jordan Criminal Law. Generality (Amman, 1996).

15. A. Kibalnik, Criminal Law 1 (2007).

16. K. al-Said. Comments to Jordan CC. Crimes against Person, (1991).

17. M. Al Halyaiya, Bulletin of the Russian University of the People's Friendship. Series: Science of Law 2, 175-177 (2000).

18. R. Peters, Crime and Punishment in Islamic Law. Theory and Practice from the Sixteen to the Twenty-first Century (New York, 2005).

19. M. R. M. Pur (Ed.), Islamic Law: Teaching Manual (2008).

20. S, A. Al-Jeneidi. Liability for Customs Crimes under Jordan Criminal Legislation: Dis. ... Cand of Jurisprudence (Moscow, 2000).

21. N. Semeryanova, O. Fedorenko, A. Kopytova, MATEC Web of Conferences 239, 04013 (2018) DOI: 10.1051/matecconf/201823904013

22. E. Vozniak, , A. Burgundosova, , A. Kopytova, MATEC Web of Conferences 239, 01016 (2018) DOI: 10.1051/matecconf/201823901016

23. E. Vozniak, , T. Slavina, , A. Kopytova, MATEC Web of Conferences 193, 04020 (2018) DOI: $10.1051 /$ matecconf $/ 201819304020$ 
24. D. Izvin, , V. Lez'Er, , A. Kopytova, MATEC Web of Conferences 170, 01065 (2018). DOI: 10.1051/matecconf/201817001065

25. A. Kopytova, MATEC Web of Conferences 106, 08056 (2017). DOI: 10.1051/matecconf/201710608056

26. V. Lez'Er, N. Semerianova, A. Kopytova, Y. Truntsevsky, E3S Web of Conferences 110, 02093 (2019). DOI: 10.1051/e3sconf/201911002093

27. R. Kolobov, U. Filatova, V. Borshcheniuk, N. Semerianova, D. Bayanov, E3S Web of Conferences 110, 02095 (2019). DOI: 10.1051/e3sconf/201911002095

28. V. Lez'Er, N. Semeryanova, A. Kopytova, I. Kvach, E3S Web of Conferences 110,02094 (2019). DOI: 10.1051/e3sconf/201911002094

29. N. Semeryanova, A. Kopytova, L. Dolnikova, V. Morozkov, MATEC Web of Conferences 239,04008 (2019). DOI: 10.1051/matecconf/201823904008

30. U. Filatova, N. Semeryanova, E. Vasilev, E3S Web of Conferences 91,08064 (2019), DOI: $10.1051 / \mathrm{e} 3$ sconf $/ 20199108064$ 